\title{
ル・コルビュジエの「装備」における標準棚の実践
}

「壁」の変容

\section{REALIZATION OF THE STANDARD CABINET AS THE “EQUIPMENT” BY LE CORBUSIER:}

Transformation of the "Wall"

千代 章一郎*1

Shoichiro SENDAI

\begin{abstract}
This paper aims to clarify the spatial composition of the standard cabinets as the "equipment" by Le Corbusier (1887-1965), in order to discuss the notion of the "decor" in the 20th century. In the private house projects, he set to study the standard cabinet as partition separated from the wall. However, he also examined the incorporated cabinets into the wall at the same time. The realization of the standard cabinets by Le Corbusier expanded to the both poles for a new notion of "wall" while continuing to the methodology of the decorative arts.
\end{abstract}

Keywords : Le Corbusier, Equipment, Standard cabinet, Wall, Mobility ル・コルビュジエ，装備，標準棚，壁，可動性

\section{1 はじめに}

本稿は、室内空間の「装飾 décor」という古典的な建築論の主題 の 20 世紀的転回について論じるために注 ${ }^{1}$ 、ル・コルビュジェ (1887 〜1965）の住宅作品における室内空間の「装備 équipement」、なか でも、その標準棚の制作手法について明らかにする。

前稿において、ル・コルビュジェの全著作の言説から、「装飾芸術」 の「家具 meuble」に対する対案として提案された「装備」の概念 の生成過程を分析し、ル・コルビュジエにおける「装備」の主題が経 年的に拡がりを見せ、建築物に付随する家具の問題から自然環境制 御する「壁」の問題にまで至っていることを明らかにした湦2)。しか しながら、言説はあくまで理念的であり、具体的な住宅建設におけ る「装備」の方法論について必ずしも明快に説明しているわけではな い。一方で、ル・コルビュジエは経年的に住宅作品を構想している が注 3 )、その多くが室内「装備」の詳細に至るまで丹念に検討され、変 更を伴っていることは、残された建築図面が示している。量産住宅 の研究などによる理論的普遍解を個人住宅の特殊解へと変換するだ けであれば、ある程度の調整を伴うにしても自動的な制作過程にな ったはずである。しかしそうでないとすれば、ル・コルビュジェに よる室内空間の「装備」は確立された方法論の機械的適用ではなく、 経年的に発展もしくは変化していくと推測される。

さて、ル・コルビュジェの「装備」の主題は、棚・机・椅子から 拡がっていくが、なかでもル・コルビュジエ自身が何より言及し、
検討を加えた要素が棚、すなわち規格化した寸法によって大量生産 して様々な組み合わせが可能な「標準棚」である注 4 )。そこで本稿では、 まずル・コルビュジエが建設事業の実践の文脈で棚について言及し ている言説を抽出して、棚を空間として実現するための方法論を導 き出す注5) (2 章)。そしてそのル・コルビュジエ独自の方法論を実 践手法として類型化し、ル・コルビュジエの全住宅作品の建築図面 に依拠して棚が検討されている事例を抽出する注6) (3 章)。その上 で、用いられている手法の変遷を明らかにする (4 章)。最後に、そ れらの変遷の理由やそれが持つ意味について考察する (5 章)。

既往研究においては、ル・コルビュジエの住宅作品における家具 の問題は付随的次項と見なされるか、もしくは家具（とりわけ椅子 や机、あるいは照明）そのものに評価を与えるものに二分される。 いずれも躯体／家具の二元論を前提としているために、内部空間の 構成要素としての「装備」の実践的内容の分析については十分な研 究が行われていない注7)。一方本稿においては、棚という可動・不動 にもなり得る要素に着目し、20 世紀における建築史の主題に空間論 としての新しい知見を得ようとするものである。

\section{2 「棚」の方法論：壁との関係性}

ル・コルビュジエが「装備」の理念について、直接的間接的に語っ ている言説は、1920 年から晚年まで経年的に認められるが、作品事 例に沿って具体的に「装備」の実践手法を解説している事例は、そ

\footnotetext{
*1 広島大学大学院工学研究科 准教授. 博士 (工学)
}

Assoc. Prof., Graduate school of Engineering, Hiroshima Univ., Dr.Eng. 
れほど多くない。

該当する最初の言説は、レスプリ・ヌーヴォー館（1925）に関す る言及である。レスプリ・ヌーヴオー館（1925）は「装備」という 概念を明確にして例証したはじめての作品であるが、しかしその設 置の手法に関しては、棚についてごく簡単に触れているに過ぎない。

「大量生産で製造され、数多くの組み合わせにしたがって並置 することのできるこれらの標準棚はバザール・ド・オテル＝ド =ヴィル[百貨店]やシャンゼリゼ大通りで販売されることにな るが、その棚は部屋の壁沿いに目一杯積みあげることも、壁と なることもできる。」注8)

ル・コルビュジエによれば、様式的な棚に代わる標準棚の数は用 途に応じて様々な組み合わせが可能であり、空間の無駄を無くすよ うに設置される。したがって、棚はどのようにも動かすことができ、 原則的に設置の手法は無限であるはずである。「壁に沿って contre the mur」設置することは、前近代的な「装飾芸術」の「家具」でも 用いられたもっとも一般的な手法であるが、レスプリ・ヌーヴォー 館（1925）において例証されるように、標準棚は脚によって空中に 浮かすこともできる。

さらに、床から天井まで覆ってしまうこともできる。しかし、レ スプリ・ヌーヴォー館（1925）には、天井に到達する棚は展示され ていない。『近代建築名鑑』(1926)に掲載された内観写真もすべて、 棚による部屋の分離を例示しているものの、完全に閉じてはいない

(Fig.1)。そもそも、「壁沿いに目一杯積みあげること」と「壁とな る constituer le mur」の言説上の区別も曖昧である

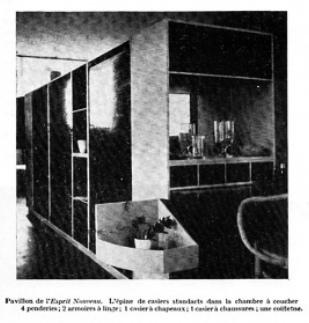

\section{UN SEUL CORPS DE MEETIER}

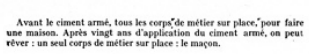

Fig.1 Cabinets of the Pavilion L'Esprit Nouveau (1925) 注9)

天井にまで到達する棚が展示されるのは、1929 年のサロン・ドー トンヌのときである。アパルトマンの一室を想定して、シャルロッ ト・ペリアンとの協働によって鋼管製の「棚」、「机」、「椅子」を展 示することが主目的であるが、その室内空間に設置された棚につい て、ル・コルビュジエは『プレシジョン』（1930）において解説し ている。

「棚を室内の壁沿いに置く人もあるでしょうし、棚を使って天 井までの、あるいは中間の高さの間仕切り壁とする人もあるで しょう（1925 年のレスプリ・ヌーヴォー館を参照）、またこの

棚を組み込んだ石積みの壁を造る人もあるでしょう。」注 $\left.{ }^{10}\right)$

棚の設置の手法は、レスプリ・ヌーヴォー館（1925）よりも細分 化されている。棚は「壁に沿って」置くだけではない。壁からは自立 して「間仕切り壁となる constituer des cloisons」こともできる。 さらに、構造的に建物を支える壁に棚を組み込んで「壁となる」こと
もできる。

こうしてル・コルビュジエは、サロン・ドートンヌ（1929）に関 する言説において、棚を配置する 3 つの手法を確立する。すなわち、 壁に「組み込むこと incorporer」、「寄せること（沿わせること） appuyer」、そして壁から離して「置くことdisposer」である注11。

しかしながら、サロン・ドートンヌ（1929）における棚の空間構 成は、この 3 つの手法をすべて例証しているわけではない。たしか に、レスプリ・ヌーヴォー館（1925）同様に、棚が空間を分節する 間仕切り壁として機能している。さらに、レスプリ・ヌーヴォー館

（1925）では実現されなかった天井まで到達する棚が、台所の手前 と奥の壁に沿って設置されている。しかし、壁に組み込まれた不動 の棚はない。天井まで到達する棚は、あくまで壁のように見えるだ けである（Fig.2）。
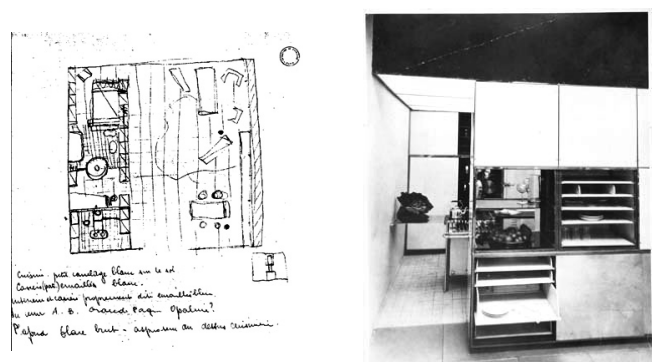

Fig.2 Sketch of the Interior of Le Salon d'Automne (1929) by Charlotte Perriand (left) and its Cabinets (right) ${ }^{{ }^{2}{ }_{12} \text { ) }}$

棚の設置手法に関する理論と実践の不整合は、展示空間だけでは なく、実作品の住宅についても当てはまる。ル・コルビュジエは『プ レシジョン』(1930) において、「豪華な邸宅の扉付き大書棚」を例 に出し、棚を壁に「組み込むこと」について説明している（Fig.3）。
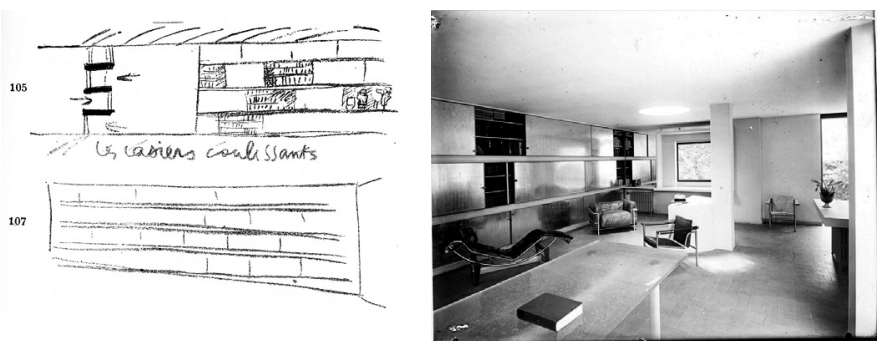

Fig.3 Sketch of the incorporated cabinets (left) and the interior of Villa Church (1929) (right) by Le Corbusier 注13)

「場合によっては棚を壁とすることによって家具を減らすこと は、鉄筋セメントの初歩的手段によって可能です。

一つの層の床と天井を描いてみましょう。そしてその高さを たとえば四つに分けます。これは鉄筋コンクリートの横板で、 厚みは数センチ、そして壁から壁へ渡っている、あるいは途中 まででもよろしい。このコンクリート板のあちら側やこちら側 に、必要に応じて壁塗をするのです。・・これですばらしい棚 =内壁が完成しました。ここに先ほどお話しした「内部装備」を はめ込めばよいのです (106)。」注14)

ル・コルビュジエが『プレシジョン』で説明する図 106 はモスク ワの軽工業省チェントロソユーズ（1929）の装備であり、図 107 の 
「豪華な邸宅」の具体名は明言されていないが、ヴィラ・チャーチ （1929）のことと思われる。ル・コルビュジエによれば、それは「壁 mur」として、内部空間から見れば内壁「paroi」を構成する注15)。

しかし実際のヴィラ・チャーチ（1929）の建設では、不動かどう かは別にして、サロン・ドートンヌ（1929）の展示と同様、壁に「寄 せること appuyer」によって棚が天井まで達して置かれている。両 者の違いは、ヴィラ・チャーチ（1929）の場合、両側壁にまで棚が 到達し、「組み込むこと」の視覚的表現がより説得力のあるものにな っていることである注 ${ }^{16}$ 。

こうしてル・コルビュジエは、『プレシジョン』において図 98 と 図 99 を用いてヴィラ・チャーチ（1929）の実践的知を活用し、次 のように言うことができた（Fig.4）。
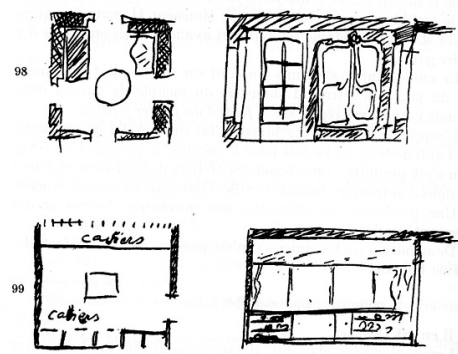

Fig.4 Sketch of plans and the sections of a conventional house and a modern house by Le Corbusier ${ }^{{ }^{1}} 17$

「新しい時代の平面図と断面図を描いてみましょう。空と間仕 切り壁と棚。随分と場所の節約です。室内をゆっくりと動き回 れます。動作は迅速、正確。整理もまるで自動的なほど思いの まま。毎日、相当な時間の節約です。この時間は貴重です(99)。」 注18)

『プレシジョン』の図 98 の組積造住宅に対する図 99 の鉄筋コン クリート住宅の対置はル・コルビュジエの常套手段であるが、柱と スラブによる鉄筋コンクリート住宅の場合、そもそも耐力壁がなく、 棚を壁に組み込むことはできないはずである。それでも「水平横長 空」の下に設置された棚注19) は、腰壁に沿って置かれているにもかか わらず、ル・コルビュジエの論理にしたがえば、横板を渡せば「組み 込むこと」に相当する。一方、空側と反対の棚は、壁とは離れている ために、厳密に言えば間仕切り壁であり、「壁のように」見えるにも かかわらず、壁からは離して「置くこと」に相当すると考えること もできる。いずれにしても、棚を「組み込むこと」「寄せること」「置 くこと」の境界は、「壁」への意識の在り方、設置のディテールなど によって大きく異なってくる。

そして以後の著作において、ル・コルビュジエが棚の空間配置の 方法論について主題的に言及することはない。

\section{3 「棚」の実践における類型}

ル・コルビュジエによる棚の空間構成についての実践的言説から、 その方法論は、「壁mur」との関係において次のように整理するこ とができる。

・棚（dis）: 壁から離して「置くことdisposer」：空中に浮かせた 棚や天井に達しない棚（dis-1）、天井に達する棚（dis-2）などがあ る。室内空間を隔離する間仕切り壁cloisonとしての機能を持つが、 壁murからは自立している。

・棚（app）：壁に「寄せることappuyer」：空中に浮かせた棚や天 井に達しない棚、天井に達する棚などがある(両側壁とは接しない)。 室内空間を隔離する機能を持つが、壁murと一部接している。前近 代的な「装飾芸術」における「家具」と配置という点では共通してい

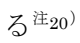

・棚（in）：壁に「組み込むことincorporer」：理論的には壁mur と一体化し内部空間の内壁parois とすることであるが(in-p)、側壁と 天井にまで達する外棚を壁に寄せることで、「壁のように」見せるこ ともできる(in-a)。

以上の 3 類型の定義に基づいて、ル・コルビュジェの全住宅の構 想を分析すると、次のような变遷の過程が得られる（Table 1）。

Table 1 Projects of private house and its cabinets by Le Corbusier ${ }^{\text {ì } 21)}$

\begin{tabular}{|c|c|c|c|c|}
\hline date & $\begin{array}{l}\text { Name of the private house projects concerved in } \\
\text { Foundation Le Corbusier }\end{array}$ & $\begin{array}{c}\text { cabinet } \\
\text { (in) }\end{array}$ & $\begin{array}{c}\text { cabinet } \\
\text { (app) }\end{array}$ & $\begin{array}{c}\text { cabinet } \\
\text { (dis) }\end{array}$ \\
\hline 1905 & Villa Fallet & & $*$ & \\
\hline 1907 & \begin{tabular}{|l} 
Villa Stotzer \\
\end{tabular} & & & \\
\hline 1907 & Villa Jacquemet & & & \\
\hline 1912 & Villa Favre - Jacot & & & \\
\hline 1912 & Villa Jeanneret-Perret & & * & \\
\hline 1916 & Villa au bord de la mer (Villa Paul Poiret) & & * & * \\
\hline 1916 & Villa Schwob & & ** & \\
\hline 1917 & Maison ouvrière & & * & \\
\hline 1920 & Maison "Citrohan" & * & & * \\
\hline 1921 & \begin{tabular}{|l} 
Aménagement de la villa Berque \\
\end{tabular} & & ** & \\
\hline 1922 & Maison d'artiste & & & * \\
\hline 1922 & \begin{tabular}{|l} 
Villa Besnus \\
\end{tabular} & & & ** \\
\hline 1922 & Maison-Atelier du peintre Ozenfant & ** & & ** \\
\hline 1923 & Maison Ribot & & * & * \\
\hline 1923 & Maison de week-end, Rambouillet & & * & ** \\
\hline 1923 & Maisons La Roche-Jeanneret & ** & ** & ** \\
\hline 1923 & Villa "Le Lac" (Petite villa au bord du Lac Leman) & & *** & $* *$ \\
\hline$\frac{1920}{1923}$ & Maisons Lipchitz:Miestchaninoff & *k & k* & ${ }_{* k}^{* k}$ \\
\hline 1923 & Maison Ternisien & ** & $k^{* *}$ & \\
\hline 1924 & Lotissement de Lège & & * & \\
\hline 1924 & Maison Canale & & ** & ** \\
\hline 1924 & Maison Casa Fuerte & ** & ** & ** \\
\hline 1924 & Maison du Tonkin & & & \\
\hline 1924 & Pavillon de l'Esprit Nouveau & & $* *$ & $* *$ \\
\hline 1924 & Villa Planeix & & \#* & $* *$ \\
\hline 1924 & Galerie-Appartement Paul Guillaume & & * & \\
\hline 1924 & Villa Marcel & & * & \\
\hline 1925 & Villa - près de Bordeaux & * & * & * \\
\hline 1925 & Villa Meyer & * & $* *$ & $* *$ \\
\hline 1925 & Villa Mongermon & & $* *$ & $* *$ \\
\hline 1926 & Maison Cumenge & & & \\
\hline 1926 & Villa Cook & & ** & *** \\
\hline 1926 & Maison Guiette & & ** & ** \\
\hline 1926 & Maison "Minimum" & *** & & $* *$ \\
\hline 1926 & Villa Joseph et Hanau & & & \\
\hline 1926 & Villa Princesse de Polignac & & & \\
\hline 1926 & Maison Atelier Dutheil & & & \\
\hline 1926 & Villa Stein-de Monzie "Les terrasses" & & & ** \\
\hline 1927 & Deux maisons du Weissenhof àStuttgart & & & ** \\
\hline 1927 & Villa Church & ** & & $* *$ \\
\hline 1928 & Villa Baizeau & & ** & $* *$ \\
\hline 1928 & Villa Ocampo & & ** & $* *$ \\
\hline 1928 & Villa Savoye "Les Heures Claires" & & ** & $* *$ \\
\hline 1929 & Appartement de M. Charles de Beistegui & $* *$ & & $* *$ \\
\hline 1929 & \begin{tabular}{|l|} 
Maison J. Canneel \\
\end{tabular} & & $* *$ & $* *$ \\
\hline 1929 & Maisons Loucheur & & & $* *$ \\
\hline 1929 & Ma Maison, Régidence-Atelier Le Corbusier & & & \\
\hline 1929 & Villa Jacquin & ** & ** & $* *$ \\
\hline 1929 & Villa Mme H. de Mandrot & & *** & $* *$ \\
\hline 1929 & Villa Paul Prado & & & \\
\hline 1929 & $\begin{array}{l}\text { Un équipement intérieur d'une habitation (Salon } \\
\text { d'automne) }\end{array}$ & ** & ** & ** \\
\hline 1930 & Maison Errazuriz & & ** & $* *$ \\
\hline 1930 & Villa Goldenberg & & & \\
\hline 1930 & \begin{tabular}{|l|l} 
Villa Harris \\
\end{tabular} & & & \\
\hline 1930 & Villa Martinez de Hoz & & & $* *$ \\
\hline 1931 & Immeuble Porte Molitor - Rue Nungesser \& Coli & & & *** \\
\hline 1933 & Petite maison, $C M A$ & & & \\
\hline$\frac{1934}{1934}$ & Maison de week-end (Henfel) & ** & ** & \\
\hline 1934 & Villa Heng & & & \\
\hline 1935 & Villa "Le Sextant", Les Mathes & & ** & ** \\
\hline 1936 & Voiture "Minimum" & & & \\
\hline 1937 & Maison de week-end Jaoul & & & \\
\hline 1938 & Maisons montées à sec : G.M.MAS & & & \\
\hline 1939 & $\begin{array}{l}\text { Maisons montées à sec : MAS [Maison Clark } \\
\text { Arundell] }\end{array}$ & & ** & \\
\hline 1949 & Villa du Docteur Curutchet & & & ** \\
\hline 1950 & Maison du Professeur Fueter & ** & & $* *$ \\
\hline 1951 & Maison du gardien, Ronchamp & & ** & \\
\hline 1951 & Maisons Jaoul & $* *$ & $* *$ & $* *$ \\
\hline 1951 & Villa de Mrs Manorama Sarabhai & ** & & \\
\hline 1951 & Maison pour Mr. Chinubhai Chimanbhai & & & $* *$ \\
\hline 1951 & Villa (Hutheesing) Shodhan & ** & & $* *$ \\
\hline 1951 & Cabanon Le Corbusier & & & ** \\
\hline 1961 & Pavillon d'exposition ZHLC (Centre Le Corbusier) & & & *** \\
\hline
\end{tabular}




\section{4 「装飾」の実践}

\section{4-1「装飾芸術」の解体}

ル・コルビュジエが「装備」という新しい概念を実践において示 し始めるのは、パリにおいて本格的に建設事業を手がけるようにな る前後のことである。

生まれ故郷のラ・ショー＝ド=フォンにおける住宅建設・改修に ついては、地元の名士・縁者・友人を顧客とし、様々な家具、壁紙、 カーテンや絨毯、照明機器まで室内装飾全般を手がけている。家具 についても、ルイ 16 世様式以降の様式家具を顧客の趣味に応じて 買い付けている注22)。雑誌『レスプリ・ヌーヴォー』においてはじ めて本格的に論評されたヴィラ・シュウォブ(1916)についても主23）、 竣工後も室内装飾に携わっているが注 24 )、鉄筋コンクリート造によ って実現された吹き抜けを介した近代的な空間構成に対して、様式 家具が壁に接して然るべき位置に置かれ、空間配置という観点から 見れば前近代的な装飾芸術の形式注25）を保持している注26）。

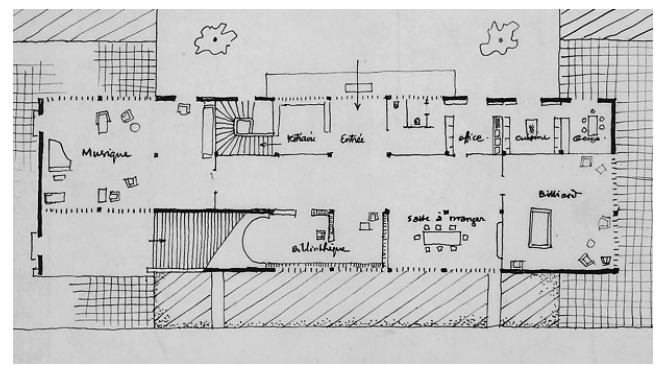

Fig.5 Plan of the Villa Paul Poiret (1916) 注27

その一方で、ル・コルビュジエは同時期、パリにおいて服飾家ポ ール・ポワレのための別荘ヴィラ・ポワレ（1916）を構想している (Fig. 5)。ヴィラ・シュウォブ（1916）と同じく鉄筋コンクリート 造であるが、ヴオールト屋根の架かる内部空間は、これまでの住宅 構想と大きく異なっている。手描きの素描しか残されていないため に詳細は不明であるが、食堂、書斎、仕事場、娛楽室などの諸室の 空間を分節しているものは、間仕切り壁に加えて、反復可能な幾何

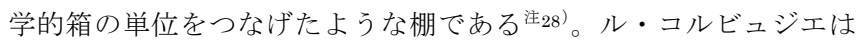
後に標準棚となるこのような棚の仕掛けを「軽い間仕切り cloisonnements légers」としていることから注29）、棚は間仕切り壁と 等価な仕掛けとして扱っていることが分かる。

構造躯体から独立し、壁から離して間仕切り壁のように空間を仕 切る棚（dis-1）は、後に「シトロアン型住宅」（1920）や芸術家の 住宅（1922）の量産住宅の研究にも適用されているが、個人住宅の 構想においてもテルニジアン邸(1923)、ランブイエの週末住宅 (1923) などにも部分的に適用されている注30）。

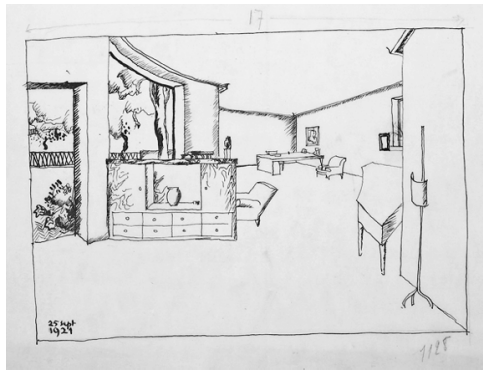

Fig.6 Perspective drawing of the Villa Berque (1921) 注31)
ヴィラ・ポワレ（1916）以後、パリでの最初の実作の一つ、ヴィ ラ・ベルクの改修（1921）では、既存の構造躯体に建具や家具を取 り付けている。従弟ピエール・ジャンヌレと協㗢をはじめたこの住 宅の内部空間の棚は、ヴィラ・シュウォブ（1916）と同様、壁に寄 せられた棚（app）に変わりないが、高さを抑えた棚が壁に接しな がら壁に対して垂直に配置されて、空間をやわらかく分節している 注32）（Fig. 6)。この手法は、レマン湖畔の両親の家（1923）をはじ め後の住宅においても多用されている。
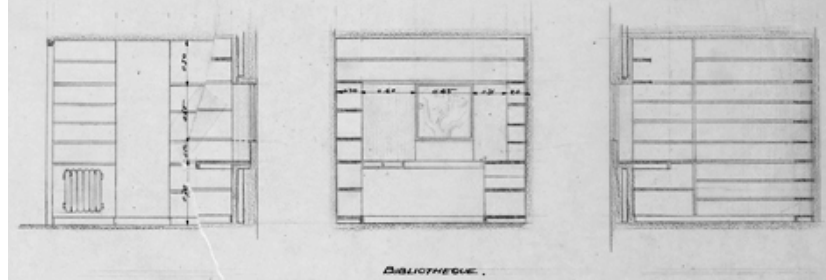

Fig.7 Cross section of the library of the Atelier Ozenfant (1922) ${ }^{\text {注 } 33 \text { ) }}$

さらに、芸術家のアトリエ住宅においては、異なる棚の配置構成 も断片的には研究されている。画家アメデ・オザンファンのアトリ エ住居（1922）や彫刻家ジャック・リプシッッのヴィラ（1923）で はアトリエが付随し、製作用具や資料のための棚が必要となるが注 34)、ル・コルビュジエはアトリエや書斎を家具のないがらんどうと するために、備え付けの棚を壁に寄せて固定し、壁のような棚 (in-a) に見せている（Fig. 7)。近代芸術蒐集家ラウル・ラニロッシュのヴ ィラ (1923) のギャラリーの棚の配置も同様である。この部屋はル・ コルビュジエの絵画を含めピュリスム絵画の展示の場所であり、壁 を展示面として利用しなければならない注35)。

以上のように、ヴィラ・シュウォブ（1916）以後、個人住宅の建 設事業に端を発し、棚を壁から自立させ（dis）、あるいは壁に垂直 に寄せること（app）、あるいは壁に見せかけること（in-a）によっ て、様式家具を壁に寄せて配置するという室内装飾芸術とは異なる 方法が萌芽的に研究されている。

\section{4-2 壁から自立する手法の拡張}

レスプリ・ヌーヴォー館（1925）には棚（in）が展示されなかっ たように、様々な条件（主として施主の要求、敷地条件、部屋の性 格）が課せられる 1920 年代から 30 年代の数多くの住宅構想におい て最も多くの適用が試みられるのは棚（dis）の可能性であり、以後 も晚年まで継続的に研究されていく。

レスプリ・ヌーヴォー館（1925）における内部空間の間仕切り壁 としての棚（dis）を特殊な解が要求される個別の住宅建設事業に純 粋に適用することは難しい。唯一の事例は、ギエット住宅（1927） である。前衛画家であった施主のために、ル・コルビュジエはほと んどすべての棚を壁からは自立して設置しようと試みている。細長 い敷地条件のために一部は壁に寄せて置いているが、書斎や婦人室 などに天井まで届かない棚（dis-1）によって空間の開放性と分節を 両立させている注 36 )。

レスプリ・ヌーヴォー館（1925）と同時期に事業が開始されたヴ イラ・プラネスク (1927) においても、レスプリ・ヌーヴォー館 (1925) における棚（dis-1）と同じ手法の適用を検討している。墓石彫刻家 の施主は、水回りの収納に至るまで細かな注文を出しているが注 37 、 
ル・コルビュジエは間仕切り壁を兼ねる棚を壁に寄せて天井まで設 置して棚（dis-2）とし、諸室と分けている。また居間と寝室も同様 の手法で、書籍の棚（dis-2）を天井まで積みあげることによって間 仕切り壁としている注38)。レスプリ・ヌーヴォー館 (1925)の棚 (dis-1) における諸室の視覚的連続性を断念し、個々の諸室の独立性を優先 する棚の手法は、ヴィラ・クック（1927）、ヴィラ・スタイン＝ド・ モンズィ（1927）など、1920 年代の多くの住宅構想においても検 討され、採用されている注39)。棚はもはや「家具」ではなく、内部空 間を分節する一つの間仕切り壁となっていると言える。

後にル・コルビュジエは、ヴィラ・スタイン＝ド・モンズィ (1927) を買い取った新しい施主に対して、次のような内部空間の維持を求 めている。

「この住宅は外観、内部の配置、そして家具が一つとなった完 全たる統一体と表現するように意図しました。この点が肝要で あること、ご配慮下さい。力説しておきたいと思います。ご希 望に応じて内部に手を入れていただいて結構ですが、全体のエ スプリの範囲内で。これこそが本当に肝要です。」注40)

ル・コルビュジエが個人住宅において意図したことは明快である。 壁と間仕切り壁としての棚（dis-2）とを等価にし、そこに自由に配 置された机や椅子に近代的素材である鋼管を用いることによって内 部空間に「統一体」をつくりだすことであった。

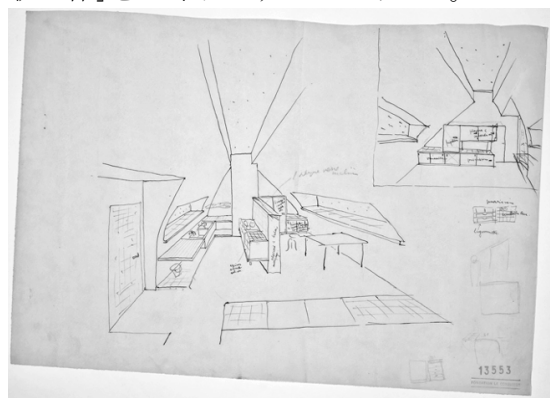

Fig.8 Perspective drawing of the Residence-Atelier, Porte Molitor (1933) by Charlotte Perriand ${ }^{\text {注 }} 41$ )

さらに、壁から自立して空間を分節する棚（dis）の手法は自在に 拡張されていく。

北アフリカのヴィラ・ベゾー（1928）は、スラブと柱の構成を純 粋化するために、外壁を後退させたり少なくしたりしてテラスとす るために、棚はより自立的になっている。ベゾー夫人の要求に応じ て、内装の一部を変更しても、外観は変わらないというわけである 注42)。ヴィラ・サヴオワ（1931）も同様である。ピロティに押し上 げられた矩形の主階は、水平横長空が外壁の四周囲にめぐらされ、 夫人の要望に臨機応変に答えて、そのスラブと柱のスケルトンのな かに棚が壁に寄せて（app）、あるいは壁から自立して（dis）（間仕 切り壁に寄せるかたちで）配置されている注43)。ポルト・モリトー ルの共同住宅の最上階の自らの自邸（1933）においても、アトリエ 以外の住居部分は「ル・コルビュジエ夫人の好みで」つくられている 注 44 ）。様々な組み合わせの標準棚（dis）が諸室を分割する機能を持 ち、可動の扉兼棚も考案されている（Fig. 8) 注45)

自立した標準棚（dis）は、施主の要望を充足するだけではなく、 ヴィラ・ベゾー（1928）のような遠隔地での施工を保証する注 46 ）。 アルゼンチンのヴィラ・マルチネス・デ・ホズ（1930）の構想にお
いては、寝室と居間が、高さを抑えた棚 $\left(\operatorname{dis}^{-1}-1\right)$ にって分節され、 サロン・ドートンヌの展示（1929）を応用して、施主の要望を反映 した標準棚によって内部空間を構成しようとしている注47)。ヴィ ラ・マルチネス・デ・ホズ（1930）以降も同じ棚（dis-1）の形式で ある。トゥーロン郊外のド・マンドロ夫人のヴィラ（1931）、チリ のエラズリス住宅（1930）レ・マットの住宅（1935）は地元の建材 と職人によるルシュール住宅（1929）の応用として構想され、施主 の要望を反映した標準棚（dis-1）が図面のなかに正確に配置され、 変更の余地のない空間を構成する注 48 )。

カプ=マルタンのル・コルビュジエの別荘、カバノン（1952）も また建材の量産化、集合住宅建設のための一つの「実験」注49) であり、 「プロトタイプ」主50) である。ル・コルビュジエが考案したモデュロ 一ル寸法に則って躯体と棚・机・寝台などが統一されているが注51）、 壁と一体化した空下の机以外、すべての棚は車輪付きの棚（dis）で あり、壁に寄せられたり、あるいは一体化しているように見えても、 可動である注52)。ル・コルビュジエがカバノン（1952）を「装備さ れた細胞」注53) と呼ぶのは、この意味においてである。

そしてル・コルビュジエの最後の住宅構想となったル・コルビュ ジェ・センター（1964）もまた、鉄骨造の傘屋根構造のスケルトン に自立した家具が挿入される注54)。アトリエの所員に、ル・コルビ ユジエは次のような指示を出している。

「私の留守のあいだに、チューリッヒホルンにおいて、さらに 後に、私たちのすべての住まいの建築物において試みることの できる棚の検討に着手するように頼みました。

1925 年、ご存じレスプリ・ヌーヴォー館に私は多大なる努力 を注ぎました。1929 年には、サロン・ドートンヌ。その後、フ ランス占領（構想は盗まれてしまいましたが）。

こうしたアイディアを再考して確実なものとしてもらいたい。 工業（可塑的な素材）との新しい関係によって実現に辿り着け るかもしれないからです。そういうわけで頼んだのであって問 題をはじめからやり直すためではありません。あなたたちのア イディアも大いに結構、しかし、この問題に関して、今日かた ちになっているものに私は自分の研究の少なからずの時間を費 やしてきたのです。」注55)

ル・コルビュジエが「問題」としているのは、工業化された建築物 同様、工業によって規格化された標準棚（dis）である。しかしなが ら、レスプリ・ヌーヴォー館（1925）において様々な壁との関係性 の可能性についてはじめて言及されたにもかかわらず、部分的には 実現しつつも、大量生産には至らなかった注56)。それでもル・コル ビュジエは、その可能性をあくまで追求する。こうしてたどり着い た結論は、カバノン（1952）にも認められた「取り外しできる棚」 注57)である。すなわち、ル・コルビュジエの棚の研究は、様々な室 内空間の装備の棚の実践によって、可動の可能性を含みつつ、壁か らの自立（dis）という点において純化していく。

\section{4-3 壁としての棚の展開}

こうして、壁から自立する棚（dis）の設置の手法が展開していく 一方で、以前から棚を床から天井まで積みあげて壁のように見せる 棚（in-a）を試みていたものの、レスプリ・ヌーヴォー館（1925） では例証されなかった棚の配置方法、すなわち壁に組み込まれる棚 (in-p)の方法が、個別の住宅建設事業で断続的に研究されている。 
この研究の動機は、1920 年代初期のアトリエの棚だけではなく、 おそらく女性のための棚の問題を端緒としている。ヴィラ・メイエ ル (1925) の構想である。財政的な問題で建設は実現しなかったが、 ル・コルビュジエと施主の打ち合わせはおもにメイエル夫人が主導 している。実際、婦人室 boudoir や寝室には自立もしくは壁に寄せ た棚（dis, app）が空間を分節する仕掛けとして多用されている注58）。 さらに、シトロアン住宅（1920）における水平横長空の腰壁と一体 化した棚（in-a）が、夫人の化粧台として適用されている（Fig. 9 右上）注59）。

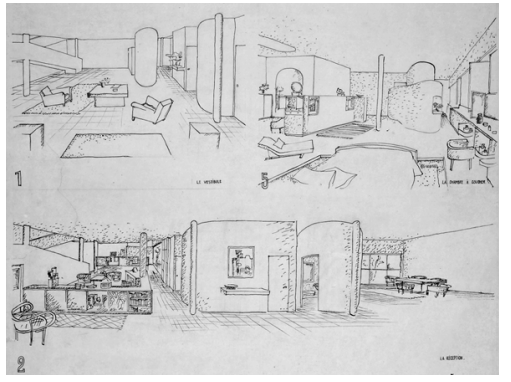

Fig.9 Perspective drawing of the Villa Meyer (1925) 注60

さらに壁全面を棚で覆っているのが、改修工事であるヴィラ・チ ヤーチ（1929）の書斎の棚（in-a）である注61）（Fig. 3）。既存の躯 体をアルミ板による引き戸棚で覆い壁と一体化させている。当時ア ルミ板は大変高価であったが、ル・コルビュジエはチャーチ氏の信 託業者にこの「大きな壁 ce grand mur」の意義を次のように説明し ている。

$「 1^{\circ}$ 重さを考えると引き戸です注 62 。

$2^{\circ}$ 次に私たちのやり方ではいかなる塗装もいたしません。 さらにす心゙てアルミニウムとしたこの書斎の大きな壁はすばら しい効果をもたらすと思っています。私たちの装飾では唯一豪 奢です。」注63

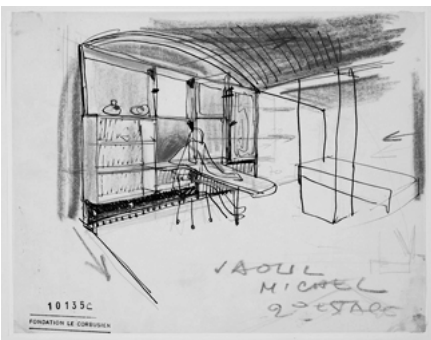

Fig.10 Perspective drawing of the Jaoul Houses (1953) 注64)

一方、1930 年頃から、シトロアン型の陸屋根ではなく、モノル型 と呼ばれるヴォールト屋根が断続的に検討されるようになる注65)。

ヴオールト屋根が架かる週末住宅（ヘンフェル住宅）（1935）に おいては、ヴィラ・チャーチ（1929）の書斎の棚（in-a）のように 壁を塞いでしまうことなく、石積の壁に埋め込むようにして棚を構 成している注66）。ヒューター博士住宅（1950）もまた週末住宅（へ ンフェル住宅）（1935）と同じ形式の空間構成であるが、棚が煉瓦 の壁自体と一体化してくる (in-p) 注67)。ル・コルビュジエによれば、 それによって「建設は単純かつ容易」注68)、さらに「自然煉瓦のざら つき」注69) を表現できるからである。

ジャウル住宅（1953）においては、空間を「分節する家具」注70) が
壁と平行もしく直角方向に構成され注71)、一部は壁と完全に一体化 している（in-p）（Fig. 10）注72）。・コルビュジエによれば、内部 空間の躯体と装備は $3.66 \mathrm{~m} \times 3.66 \mathrm{~m}$ のモデュロール寸法に則ること によって、「自由な空間」注73) が得られるのであり、一定の寸法体系 を典拠として、壁／棚の二元論が統合されている。

さらにこの棚（in-p）の形式は、インドのアーメダバードにおけ る住宅建設でも適用されている。ヴィラ・サラバイ（1955）の構想 においては、はじめから自立する棚は検討されずに、並列する筒状 のヴォールト空間の壁面に棚を埋め込む検討がなされている注 74 ）。 それは明確にジャウル住宅（1953）における棚（in-p）の装備の可 能性を追求したものであるが注75)、同時にインドの伝統的な住まい の形式、すなわち換気を旨として家具を減らして通風を確保し、寝 台を中心とした住居として適応させるためのものでもある注 76 。し たがって、「家具」と言えるものは、もはやかっての棚・机・椅子の 分類によるものではなく、椅子よりも床面に近い寝台のみとなる注 77)。こうしてル・コルビュジエは、この新しい「壁」の探求をさらに 推し進め、ヴィラ・サラバイ（1955）の「壁」に写真壁画さえ構想す るのである注78)。実際、この住宅を訪れたル・コルビュジエの印象 によると、サラバイ夫人が所有する、棚＝壁に収まらない芸術作品 や骨董家具は「住宅の環境、雾囲気、精神を殺す」注79)ことになりか ねない。

モノル型のヴォールト屋根の住宅において、棚（in-p）が壁に組 み込まれていくのに関連して、同じくアーメダバードの住宅として 構想された陸屋根のシトロアン型のチマンバイ住宅 (1952) やその 構想を引き継いだヴィラ・ショーダン（1956）においても、カバノ ン（1952）における装備の自立性や可動性とは異なる躯体との一体 化が追求されている湦80)。やはりインド固有の寝台生活と関わりが あり注81)、モノル型住宅のような重厚な壁は存在しないが、ヴィラ・ ベゾー（1928）とは異なり、柱間を塞ぐ壁や間仕切り壁に棚（in-p） が組み込まれている。こうしてル・コルビュジエは、所謂「近代的な 様式」や豪華な素材を使うこと戒め、伝統的な生活を尊重しながら、 「単純性」注82）を追求する注83)。

ル・コルビュジエはヴィラ・ショーダン（1956）を「避難所」と呼 んで回想している。

「ショーダンに何を与えたのか? 宮殿である＝機能的な住宅で ある。ショーダンの財産と打ち放しコンクリートと色彩を使っ て、私が与えたもの：夏の日陰、冬の太陽、年中の冷気の循環。 まっとうな部屋がある。各々の部屋＝避難所＝小さな家がある。 1 階の小さな部屋を出て 2 階のテラスへ。そこは日陰であり避 難所である。空気は常に循環する。屋根に登って寝る。主人や 来客はどこでも避難所にいて、魅了され、満足している。ロワ 一ルの城であろうか?そう、知的な王子様」注84)

棚（in-p）が壁面となったヴィラ・ショーダン（1956）に繰り広 げられる生活は、最小限かつ根本的な「避難所」としての住まいであ る。そこは「城」でありながら豪奢なものは何もなく、自然と同調 する自由な活動があり、それを阻害する家具や器機はない注85)。力 バノン（1952）における「装備された細胞」とは異なる生活空間像 である。 
unitl the Pavilion L'Esprit Nouveau (1925) the villas after 1925 the villas from the 1940 's
Decorative Arts in France

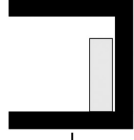

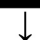

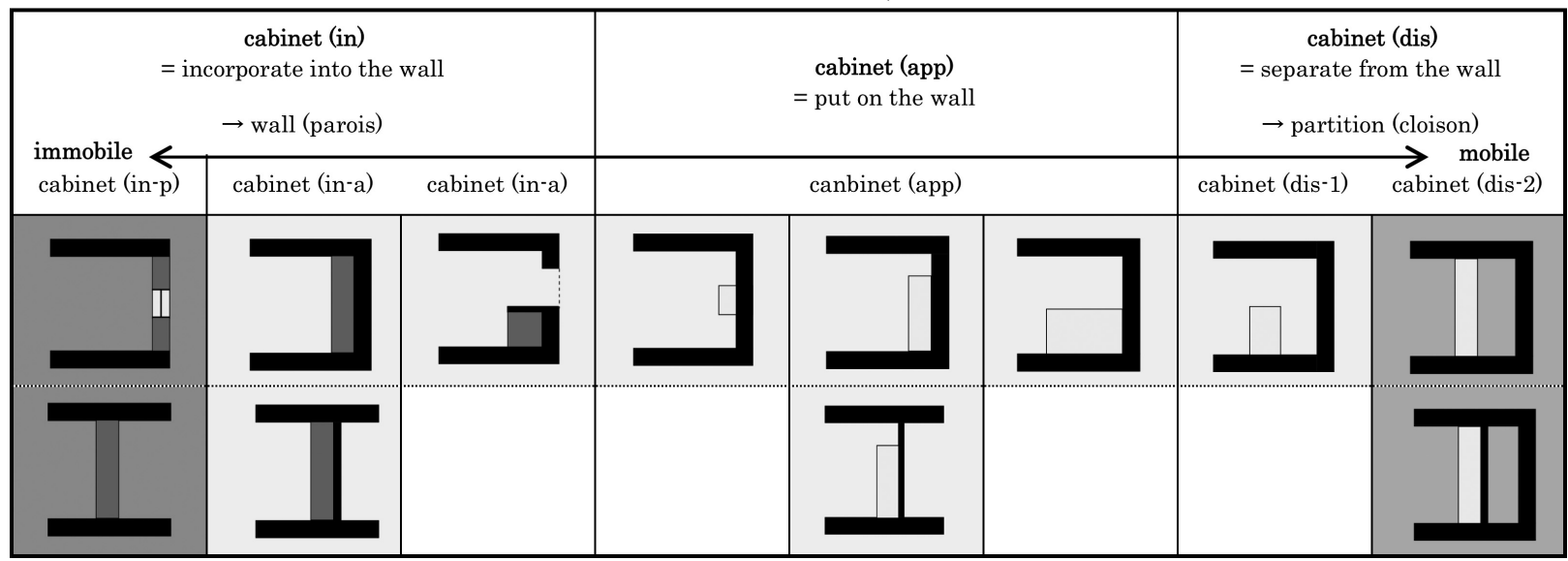

ル・コルビュジエはすでに 1929 年のサロン・ドートンヌの展示 の頃に、理論的には 3 類型、すなわち壁に寄せる棚（app）、壁から 自立する棚（dis）、壁に組み込む棚（in）の方法論を言説として確 立している。しかし棚の空間配置の 3 つの手法に依拠してル・コル ビュジエの住宅建設構想を経時的に分析すると、1925 年のレスプ リ・ヌーヴォー館の建設以前から棚（dis）や棚（in）を構想してい るものの、壁に寄せて棚（app）を置くという伝統的な装飾芸術の 手法に依拠しつつ、棚自体が空間を分節する仕掛けを検討している 事例が多いことが分かる注87。

その後、1920 年代から 30 年代の様々な住宅建設事業を通して棚 の実践を試みる過程において、一方では壁面から棚（dis）が自立す るようになり、第二次世界大戦後においても継続的に検討されてい る。それは室内空間を分節する仕掛けとしての機能を追求する過程 で考案されたものであるが、第一次世界大戦後の量産住宅研究や、 遠隔地での建設という機会が大きく影響している。すなわち、建築 家がすべての建設過程を管理制御することなく、棚（dis）を部品化 して自動的に設置するために、不動の壁からは切り離しておく必要 がある。それは翻って、施主の様々な要求の詳細に答えることにも 有効である。この棚（dis）は、第二次世界大戦後も継続的に研究さ れ、最終的には壁から自立しているだけではなく、それ自体が容易 に可動な棚として研究されていく。

他方、1920 年代には外見的にしか実現し得なかった、壁と一体化 した棚（in-p）がモノル型のヴォールト屋根を架けた住宅を契機に 断続的に検討されていく。床とスラブを構造的な骨組みとする陸屋 根のシロトアン型においては、棚そのものを空間を分節する仕脚け として検討することができるが、モノル型はヴオールト屋根を支持 する壁体の多さから、そこに棚を組み込むことが検討され、インド の気候風土においてさらにその可能性が追求されていく。

このように、ル・コルビュジエによる棚は線型に展開するわけで はなく、装飾芸術の方法論を継承しつつ、両極に多様に拡がってい
く（Table 2)。一見矛盾するが、しかし可動する棚を一時的に所有 するにせよ、棚を壁に組み込んでしまうにせよ、最終的に「家具」は 残らない。

ル・コルビュジエは新しい時代の生活を「ノマド」すなわち状況 に応じて暮らしを変えることとしているが注88)、棚（dis）はその要 求に応えるものであろう。しかし棚（in）がはじめから住宅に備わ っていれば、人間は何も持つ必要はない注89)。そしてそのまるでア トリエのがらんどうのような空間に、放牧生活とは矛盾するかのよ うな「孤独と静寂」がつねに意識されている注90)。ル・コルビュジエ の棚、すなわち間仕切り壁であり壁であるような新しい「壁」の研究 の拡がりは、ル・コルビュジエの「ノマド」の住まいについての滞留 と移動の両義的なヴィジョンの反映と考えることができる。

\section{参考文献}

1) Amano, C.: Decoration and Art, Brucke, Tokyo, 2001

2) Barré-Despond, A., et al.: Francis Jourdain 1876-1958, Somogy Éditions, Paris, 2000 (in French)

3) Barsac, J.: Charlotte Perriand, Complete Works, Vols.3, Scheidegger \& Spiess, Zurich, 2014-2017

4) Cinqualbre, O. and Migayrou, F., dir.: Le Corbusier, Measures of Man, Éditions du Centre Pompidou, Paris, 2015 (in French)

5) Jeanneret, C-É.: Study on the Movement of Decorative Art in Germany, Haefeli et Cie, La Chaux-de-Fonds, 1912 (in French)

6) Jeanneret, C-É.: The Voyage to Germany, Sketchbook, Electa, Milano, Fondation Le Corbusier, Paris, 2000 (in French)

7) Jeanneret, C-É.: The Voyage to the East, Sketchbook, Electa, Milano, Fondation Le Corbusier, Paris, 2000 (in French)

8) Kries M., ed.: Le Corbusier, A Study of the Decorative Art Movement in Germany, Vitra Design Museum, Weil am Rhein, 2008

9) Le Corbusier: Archive of Correspondences, Fondation Le Corbusier, 1907-1965 (in French)

10) Le Corbusier: Archive of Planss, Fondation Le Corbusier, 1907-1965 (in French)

11) Le Corbusier: Decorative Art of Today, G. Crès et Cie, Paris, 1925 (in French)

12) Le Corbusier: Almanac of Modern Architecture, Les Éditions G. Crès 
et Cie, Paris, 1926 (in French)

13) Le Corbusier: Complete Works, vols.8, Girsberger, Zürich, 1929-1970 (in French)

14) Le Corbusier: Precision on the Present State of Architecture and City Planning, G. Crès et Cie, Paris, 1930 (in French)

15) Le Corbusier: The Modulor, Les Éditions de L'Architecture d'Aujourd'hui, 1950 (in French)

16) Le Corbusier: Modulor 2, Les Éditions de L'Architecture d'Aujourd'hui, Paris, 1955 (in French)

17) Le Corbusier: Le Corbusier Sketchbooks, Vols.4, Fondation Le Corbusier, Paris, The Architectural History Foundation, New York, Éditions Herscher / Dessain et Tolra, Paris, 1981, 1982 (in French)

18) Le Corbusier-Saugnier: Toward a New Architecture, G. Crès et Cie, Paris, 1923 (in French)

19) Le Corbusier: Tapisseries Muralnomad, Zodiac, $n^{\circ} 7,1960$ (in French)

20) Lucan, J., dir.: Le Corbusier an Encyclopaedia, Les Éditions du Centre Pompidou/CCI, Paris, 1987 (in French)

21) Mizuno, Y.: Wall and Mur, International Research, No.4, pp.209-231, 1987.6. (in Japanese)

22) Perriand, C.: A Life of Creation, Éditions Odile Jacob, Paris, 1998 (in French)

23) Rüegg, A.: Le Corbusier, Interior Furniture 1905-1965, Verlag Scheidegger \& Spiess, Zurich, 2012 (in French)

24) Samuel, S.: Le Corbusier in Detail, Architectural Press, Oxford, 2007

25) Sendai, S.: Formation of the Notion on "Equipment" by Le Corbusier, Journal of Architecture and Planning (Transactions of AIJ), No.739, pp.2411-2419, 2017.9. (in Japanese)

26) Troy, N.: Modernism and the Decorative Arts in France, Yale University Press, New Haven and London, 1991

注

*引用は寸心゙て原文のまま。但し、［］潷者による補注

注1）たとえば、20世紀前半の「装飾芸術 art décoratif」は単に付加的要素 ではなく、家具、食器、壁紙、タペストリー、家具、照明機器、場合によ っては服飾なども含む包括的な概念として「装飾」と捉えることができ、装 飾否定としての近代という図式を再考する必要がある。cf., Nancy Troy, Modernism and the Decorative Arts in France, Yale University Press, New Haven and London, 1991

注2）千代章一郎、「ル・コルビュジエにおける「装備」概念の変容」、日本 建築学会計画系論文集、第 82 巻、第 739 号、2017 年 9 月、pp.2411-2419 参照。

注3）室内空間の「装備」は、ル・コルビュジェの場合、オフィスやミュージ アムなど、住宅という建築類型に限らない。しかし「装備」の出自は、日常 生活への問いと根本的に関連しているために、本稿ではとくに住宅の最小 単位である個人住宅に焦点を絞っている。ル・コルビュジエの場合、ブル ジョワの郊外週末住宅、芸術家のアトリエ住宅、芸術愛好家の住宅、婦人 の住宅、自邸が住宅における「装備」の中心課題を構成している。量産住宅 については、個人住宅と明らかに関連性が認められる場合には注記するが、 ル・コルビュジエの場合、個人住宅の研究に着想を得て量産住宅に一般化 していることから、本稿では主題的に扱っていない。

注4) “ casiers standarts ». cf., Le Corbusier, Almanach d'architecture moderne, Les Éditions G. Crès et Cie, Paris, 1926, p.113.

注5）本稿においては、空間論という観点から、棚そのもののデザインの特徴 や様式の問題については言及していない。

注6）図面がなく竣工時には実現している室内装備の事例も存在し、竕工時の 写真などから実現した住宅作品の装備の実態を検証する作業も必要である が、本稿では、建築家の構想過程を主題とすることから、図面上の検討そ のものを分析の対象としている。

注7）代表的な研究としては、以下である。cf., Flora Samuel, Le Corbusier in Detail, Architectural Press, Oxford, 2007; Arthur Rüegg, Le Corbusier, Meubles Intérieurs 1905-1965, Verlag Scheidegger \& Spiess , Zurich, 2012; Cloé Pitiot, " Le Corbusier, le mobilier corps et âme ", sous la direction d'Olivier Cinqualbre et Frédéric Migayrou, Le Corbusier, mesures de l'homme, Éditions du Centre Pompidou, Paris, 2015 pp.85-89.

注8) “Établis en série, ces casiers standarts juxtaposables suivant de multiples combinaisons, pourront être vendus au Bazar de l'Hôtel-de-Ville ou à l'Avenue des Champs-Élysées; ils se mettent contre le mur à toute hauteur, ou constituent le mur. " (Le Corbusier, Almanach d'architecture moderne, op.cit., p.113)

注9) 出典: Le Corbusier, Almanach d'architecture moderne, Les Éditions G. Crès et Cie, Paris, 1926, p109.

注10) “L'un disposera les casiers contre les murs de ses chambres ou constituera avec eux des cloisons nouvelles à pleine hauteur ou à mi-hauteur (voir Pavillon de l'Esprit Nouveau, 1925) ; l'autre construira ses murs en incorporant les casiers dans les maçonneries. " (Le Corbusier, Précision sur un état présent de l'architecture et de l'urbanisme, G. Crès et Cie, Paris, 1930, p.108, p.115)

注11) cf., Le Corbusier et Pierre Jeanneret, Euvre complète 1910-1929, Girsberger, Zürich, 1929, p.100.

注12) 出典 : AFLC, F1-3-78; AFC, L1-20-15. 写真手前の棚は、奥に見える 台所を隔離するために天井まで到達する棚を壁から離して「置く」。台所の 奥に見える天井まで到達する棚は壁に「組み込む」ように見えるが、実際 には壁に「寄せる」。

注13) 出典 : Le Corbusier, Précision sur un état présent de l'architecture et de l'urbanisme, G. Crès et Cie, Paris, 1930, p.117; AFLC, Archives Villa Church.

注14) «La réduction du mobilier à l'état de casiers constituent à l'occasion le mur lui-même peut être obtenue aussi par des méthodes rudimentaires de construction en ciment armé :

Je dessine le plafond et le plancher d'un étage : je divise la hauteur en quatre secteurs par exemple, au moyen de trois planchers de béton armé, épaisses de quelques centimètres, allant d'un mur à l'autre ou s'arrêtant à mi-parcours. Je maçonne tantôt sur un bord de mes planches de béton, tantôt sur l'autre, suivant les besoins. ... Voici de magnifiques parois-casiers dans lesquelles s'inséreront les " équipement intérieurs " dont j'ai parlé déjà (106). " (Le Corbusier, Précision, op.cit., p.108, pp.115-116)

注15）ル・コルビュジェが「壁 mur」「間仕切り壁 cloison」「内壁 paroi」を 厳密に使い分けているかどうかは定かではない。語源的には、躯体構造を 支持する耐力「壁 mur」とその内部を仕切る「間仕切り壁 cloison」、そして それらとは別に内壁そのものを意味する「内壁 paroi」があり、このニュアン スが現在の用語法にも影響を与えている。水野豊、「<壁 $>$ と $<$ Mur $>$ 小 国際研究、No.4、1987.6. pp.209-231参照。

注16)『プレシジョン』（1930）において、ル・コルビュジエが棚を壁に「組 み込むこと」について言及しているもう一つの実作品は、モスクワの軽工 業省「ツェントロソユーズ」（1929）であるが、やはり側壁は外壁に接し ているという点において、ヴィラ・チャーチ（1929） と共通した修辞法を 用いている。cf., Le Corbusier, Précision, op.cit., p.116.

注17) 出典: Le Corbusier, Précision sur un état présent de l'architecture et de l'urbanisme, G. Crès et Cie, Paris, 1930, p.110.

注18) « Je dessine en plan et coupe un dispositif moderne: fenêtre, cloisons et casiers. J'ai gagné une place considérable; on peut circuler à l'aise; les gestes seront rapides et exacts; le rangement automatique. Ce sont des minutes gagnées, chaque jour; précieuses minutes (99.)" (Le Corbusier, Précision, op.cit., pp.109-110)

注19) cf., [Le Corbusier], FLC20705; [Le Corbusier], FLC20707A. この腰 壁=棚の空間図式は図面で確認される限りシトロアン住宅（1920）が初出 であり、後の 1920 年代の住宅構想においてしばしば用いられるが、ヴィ ラ・ラ・ロッシュ（1923）の書斎や隣接するヴィラ・ジャンヌレ (1923) の居間などが初期の事例である。しかしレマン湖畔の両親の家（1923）は 典型的な水平横長空を有する住宅であるにもかかわらず、空下には棚は設 置されていない。固定されているのは机のみであり、ル・コルビュジェは、 この空／机の関係につねに執着している。cf., Le Corbusier, Le Corbusier Carnets 3 1954-1957, Fondation Le Corbusier, Paris, The Architectural History Foundation, New York, Éditions Herscher / Dessain et Tolra, Paris, 1981, p.1053, 1957.11.3. 空/机はカバノン（1952）にも認められ 
る空間図式であるが、明らかに 1911 年の東方への旅で訪れた僧院や農家 の風景に起源をもっている。cf., Le Corbusier, Le voyage d'orient, Les Éditions Forces vives, Paris, 1966, pp.20-21.

注20）フランシス・ジュルダンの家具などは、壁面との一体化の最初の試み の一つであるが (cf., Arthur Rüegg, op.cit., pp.58-59)、少なくともル・コ ルビュジエの『装飾芸術』（1925）において批判される「装飾芸術」は壁 に寄せて置くことのできる家具である。cf., Le Corbusier, L'art décoratif d'aujourd'hui, G. Crès et Cie, Paris, 1925, pp.146-164.

注21）出典：筆者作成。図面において検討が確認される棚のリストであり、 図面化を経ずに建設された例もあるために、実態とは必ずしも一致しない。 なお、竣工時の年代へ表示しているが、本表のリストの年代は、ル・コル ビュジェ財団目録にしたがって図面による検討がはじまる時期としている。

注22） cf., AFLC, CARNET25-6440 6465; [Le Corbusier], FLC6462.

注23) cf., Juline Caron, "Une villa de Le Corbusier 1916 ", L'Esprit Nouveau, $\mathrm{N}^{\circ} 6,1921.3$, pp.679-704.

注24) cf., AFLC, lettre de Charles-Édouard Jeanneret à Mme Schwob, R3-3-192, 1923.10.28.

注25）「装飾芸術」の近代化運動の萌芽はすでに存在していたが、1925 年にパ リで開催された近代装飾芸術・工業芸術国際博覧会は、ル・コルビュジエ を含む様々な運動のなかで「装飾芸術」の大きな転換期となったとされる。 天野知香、『装飾／芸術-19 世紀フランスにおける「芸術」の位相』、ブリ ユッケ、2001 参照。

注26） cf., [Le Corbusier], FLC6462. もちろん、「装飾芸術」を超える試みが 断片的には行われていた。すでにドミノ・システムによる住居の構想では、 棚は量産で作り付けるとしている。cf., Le Corbusier-Saugnier, Vers une architecture, G. Crès et Cie, Paris, 1923, p.197.

注27) 出典 : [Le Corbusier], FLC30281.

注28) cf., [Le Corbusier], FLC30281.

注29）cf., Le Corbusier-Saugnier, op.cit., p.204. 直後に構想された「モノル 型住宅」と呼ばれるヴォールト屋根の量産住宅においても、天井にまで達 しない棚が壁に対して直角に置かれ、空間を緩やかに仕切っている。cf., Ibid., p.205.

注30）ただし、ランブイエの週末住宅（1923）の場合、構想の過程で壁から 離していた棚が壁へ寄せて置くように配置を変更している。cf., FLC30071; [Le Corbusier], FLC30069.

注31) 出典 : [Le Corbusier], FLC9316, 1921.9.25.

注32）比較的高さを抑えた壁寄せの棚の方法は、集合住宅イムーヴル・ヴィ ラ（1922）の住戸にも適用されることになる。cf., Le Corbusier-Saugnier, Vers une architecture, G. Crès et Cie, Paris, 1923, p.208.

注33) 出典: FLC7837.

注34) cf., AFLC, H1-17-18, lette de Pierre Jeanneret à Amédée Ozenfant, 1925.6.5; AFLC, H1-1-27, lettre de Jacques Lipchitz à Charles-Édouard Jeanneret, 1924.3.21.

注35) cf., AFLC, P5-1-208, lettre de Charles-Édouard Jeanneret à Amédée Ozenfant, 1925.4.16. ただし、構想の初期段階では自立した棚がキャラリ 一の中央部に設置されているが、最終的には斜路下に組み込まれている。 1928 年の改修時には、スライド式の棚に変更されている。cf.,[Le Corbusier], FLC15294D; FLC15205; [Charlotte Perriand], FLC15290.

注36) cf., [Le Corbusier], FLC8594A, 1926.2.28. 同じような細長い敷地の カネール住宅（1929）も同じ棚の配置である。cf., FLC8519; FLC8535.

注37) cf., FLC8973.

注38) cf., FLC8902, 1926.5.28; FLC9238.

注39）ヴィラ・クック（1927）の棚の検討については、cf., [Le Corbusier], FLC8588; FLC8349; FLC8309。スタイン＝ド・モンズィ（1927）の棚の 検討については、cf., FLC10494。いずれも、台所と居間の空間を分節する 棚であり、詳細な見積もり文書も残されている。cf., AFLC, H1-6-200, Devis des travaux de menuiserie, reçu. 1926.11.23. また、個別の住宅建 設ではないが、実験住宅の実現であるヴァイゼンホフ・ジートルングの 2 つの住宅（1927）の 2 戸建て住宅（C2）における台所・居間・寝室の分節 も同様の天井まで接する自立棚である。

« Je reçois v. amicale lettre du $8 \mathrm{o}^{\mathrm{t}}$. Je trouve très heureuse votre idée de meubler les 2 maisons comme si elles étaient habitées. Mon opinion sur le genre de meuble? Cela m'est tout à fait égal, avec cette réserve que le mobilier ne doit comprendre que des tables et des sièges, et pas de buffets ou armoires, presque tout le nécessaire existe pour chaque pièce : les sièges peuvent être très différents les uns des autres, pour le travail, pour le repos, la lecture, la conversation etc. Les tables pourraient être standart et juxtaposable faisant ainsi de petites ou de grandes tables. " (cf., AFLC, H1-11-220, lettre de Le Corbusier à A. G. Schmeck, 1928.2.10)

「10月 8 日のご丁寧な手紙を拝受しました。2 戸の住宅が住まわれること になったら備え付ける家具についての考え方はとても優れていると思いま す。家具というものについての私の意見ですか?まったくもって[建物と] 同じことです。家具とは机と椅子だけで、食器棚や洋服棚はありません。 それらの机と椅子を部屋に応じて必要なものを備えておけばよいのです： 椅子は仕事、休息、読書、おしゃべりなどによって異なります。机は規格 化し、大小を組み合わせて並べればよろしい。」

注40) “Cette maison a été conçue pour présenter une unité complète de l'extérieur, de la disposition intérieure et le mobilier devrait être faite à l'unisson. Vous vous rendrez compte que c'est là un point capital. J'insiste beaucoup sur ce point que nous aimerions vous aménager l'intérieur conformément à vous désirs, mais dans l'esprit général de l'ensemble. C'est véritablement une espèce de nécessité. " (AFLC, H1-4-111, lettre de Le Corbusier à M. Steen, 1935.10.4)

注41) 出典 : [Charlotte Perriand], FLC13553.

注42) cf., FLC8488; AFLC, H1-10-31, lettre de Pierre Jeanneret à Madame Baizeau, 1929.6.5.

注43) cf., AFLC, H1-12-66, lettre de Pierre Jeanneret à Madame Savoye, 1929.8.24.

注44) cf., AFLC, H2-1-430, Document état locatif, s.d.

注 45 ) cf., [Charlotte Perriand], FLC13352; [Charlotte Perriand], FLC13553; FLC13450; FLC13872.

注46）遠隔地における建設の問題が、ルシュール住宅（1929）の乾式工法の 量産住宅研究に結びついている。これはペサックのフルージェス近代地区 （1924）に打ける工場生産研究に起因する最小限住宅（1926）の延長線上 にあるが、様々なヴァリエーションの検討のなかで、水回りがユニット化 して独立し、棚が自立して空間を分割している。cf., FLC18240.

注47) cf., AFLC, I1-17-23, lettre de Le Corbuseir à Julien Martinez, 1930.12.3; [Le Corbusier], FLC24131; [Charlotte Perriand], FLC24126.

注48) cf., AFLC, H3-2-8, lettre de Le Corbusier à Madame Hélène de Mandrot, 1931.12.6. アルゼンチンのヴィラ・クルチェット（1949）は鉄 筋コンクリート構造であるが、通風の確保のために壁ではなくカーテンに より遮光し、やはりドミノのスケルトンに自立する棚を厳密に位置づけて いる。 cf., AFLC, I2-7-113, lettre de Le Corbusier à Germaine Curatelle-Manes, 19854.1.14.

注49) cf., AFLC, M2-9-66, lettre de Le Corbusier à Robert Rebutato, 1950.5.4.

注 50 ) cf., AFLC, M2-9-82, lettre de Le Corbusier à Jeanne Veret, 1952.12.37.

注 51) cf., Le Corbusier, Modulor 2, Les Éditions de L'Architecture d'Aujourd'hui, Paris, 1955, pp.253-255.

注52）cf., FLC24335；FLC24340. 机だけが壁に固定されているのは、おそ らくル・コルビュジエがカバノン（1952）建設地近くで発見して参照した 農家の研究と関係している。その農家には家具は描かれず、正方形の空の 下に机が備えてあるだけである。cf., AFLC, Album Nivola, W1-8-110, 1951.8.12.

注53) cf., « la celleule équipée », cf., Le Corbusier, Le Corbusier Carnets 4 1957-1964, Fondation Le Corbusier, Paris, The Architectural History Foundation, New York, Éditions Herscher / Dessain et Tolra, Paris, 1982, p.1010, 1963.7.23.

注54） cf., Le Corbusier, FLC21078, 1961.12.12; Le Corbusier, FLC21079, 1961.12.12; Le Corbusier, FLC21081, 1961.12.12.

注55) “Je vous ai demandé de mettre à l'étude, pendant mon absence, les casiers dont l'expérimentation pourrait se faire à Zurichhorn et, plus tard, dans tous nos bâtiments d'habitation.

J'ai consacré des efforts très grands, en 1925, au Pavillon de l'Esprit Nouveau que vous connaissez; en 1929, au Salon d'Automne; plus tard, pendant l'Occupation (les plans ont été volés). 
Je vous demande de reprendre ces idées et de les mettre au point définitivement car les nouveaux contacts avec les industriels (matière plastique) permettent d'envisager un début de réalisation. C'est cela que je vous ai demandé et non pas de recommencer le problème entièrement. Je ne vous interdis nullement d'avoir vos idées, mais, dans ce problème, je tiens à ce que l'on réalise aujourd'hui les choses auxquelles j'ai consacré une part importante de mes recherches. " (AFLC, F1-3-316, Note à l'attention de l'Atelier, 1962.4.3)

注56) cf., Charlotte Perriand, Une vie de création, Éditions Odile Jacob, Paris, 1998, p.250.

注57) " casiers amoviles ", cf., AFLC, F1-3-245, lettre de Le Corbusier à Ignacio Pivovano, 1950.6.2.

注58）ル・コルビュジエはメイエル夫人とは面会して詳細な打ち合わせを行 っているはずであるが、残された文書は工事見積もりに関するものが大半 である。

注59） cf., [Le Corbusier], FLC31514; FLC10370, 1926.4.21. 実質的には ル・コルビュジェの兄の妻ロティ・ラーフのためのヴィラ・ジャンヌレ (1923) の居間などもまた、同じ水平横長空と棚の構成である。

注60) 出典: [Le Corbusier], FLC31514.

注61） cf. FLC31463；FLC31464；FLC8190 改修のためか、この素描を正確 に反映する平面図や断面図は残されていない。ベイステギのアパルトマン の改修 (1931) における図書室の棚についても同じ手法が適用されている。 cf., FLC17499; FLC17431, 1929.6.3.

注62）引き戸の棚は、開き戸や引き出し戸に比べると、比較的遅い時に採用 されている。初出はアトリエ・ルコルビュにペリアンが入所した時期、1928 年のヴィラ・ラ・ロッシュの改修によるギャラリーの棚の頃からであり、 1927 年よりアトリエに入手したシャルロット・ペリアンによる寄与が大き い(cf., Charlotte Perriand, op.cit., p.23, p.60.)。また同時期にアトリエに 在籍した前川國男の影響という推測もあるが (cf., Jacques Barsac, Charlotte Perriand, Complete Works, Volume 1 1903-1940, Scheidegger \& Spiess, Zurich, 2014, p.122)、典拠は定かではない。

注63) “ $1^{\circ}$ Les coulissants seront plus facile à manier à cause du poids. $2^{\circ}$ Nous avons de suite une manière propre sur laquelle nous n'aurons aucune peinture à faire, en plus de cela nous pensons que dans la bibliothèque, ce grand mur en entier en aluminium sera d'un très bon effet, ce sera le seul luxe de notre décoration. " (AFLC, H3-3-97, lettre de Le Corbusier à Moreau Lanande, 1929.1.21)

注64) 出典: Michel, FLC10135C.

注65）モノル型住宅は芸術家の住宅（1922）に遡るが、当時はヴォールト屋 根天井採光のある鉄筋コンクリート構造のアトリエの空間に最小限の自立 する棚が配置されている。cf., [Le Corbusier], FLC30198.

注66) cf., [Le Corbusier], FLC9250; FLC24229; FLC9254.

注67) cf., Le Corbusier, FLC18515, 1949.11.10; FLC18504, 1950.6.27; FLC18506, 1950.6.27.

注68) " la conctruction est si simple, si facile que votre architecte entrepreneur peut certainement la réalisation sur place. ", cf., AFLC, I2-7-137, lettre de Le Corbusier à Professeur Fueter, 1949.11.14.

注69) “ la rudesse des briques brutes ", cf., AFLC, I2-7-141, lettre de Le Corbusier à Professeur Fueter, 1950.3.17.

注70) " meuble de séparation », cf. AFLC, J1-14-413, lettre de Le Corbusier à Charles Barberis, 1955.3.21.

注71) cf., Le Corbusier, FLC10099, 1952.3.1.

注72) cf., Michel, FLC10135C; FLC10037; FLC10169.

注73) “l'intérieur des espace libres ", cf., AFLC, J1-14-396, lettre de Le Corbusier à Charles Barberis, 1955.1.4.

注74） cf., FLC31884, 1952.6.12; Véret, FLC6709, 1953.4.24.

注75) cf., AFLC, P3-7-57, lettre de Doshi à Jean-Louis Véret, 1953.9.8.

注76) cf., AFLC, P3-7-84, lettre de Tobito à Jean-Louis Véret, 1954.10.20.

注77）実際、ル・コルビュジェは壁面の煉瓦以上に、床面の建材を研究し、

伝統的な地元産の自然石材を採用している。cf., AFLC, P3-7-86, lettre de Tobito à Jean-Louis Véret, 1954.10.20; P3-5-201, lettre de Le Corbusier à Manorama Sarabhai, 1954.15.3.

注78) cf., [Le Corbusier], FLC6725; Le Corbusier, Le Corbusier Carnets 3 1954-1957, op.cit., p.42, 1954.2.24; AFLC, P3-5-502, Note pour Michel dictée par L-C, 1954.3.24.

注 79) " l'ambiance, l'atmosphère, l'esprit de la maison ", cf., AFLC, P3-5-223, lettre de Le Corbusier à Manorama Sarabhai, 1956.5.1.

注80） cf., Doshi, FLC6357, 1954.1.17; Doshi, FLC6367, 1954.1.17; Doshi, Véret, FLC6409A, 1953.5.20, 1954.1.30; Doshi, Véret, FLC6419A, 1953.5.19, 1954.1.30.

注81) cf., AFLC, P3-5-367, lettre de Le Corbusier à Chinubhai Chimanbhai, 1954.4.26.

注 82 ) 《 simplicité ", cf., AFLC, P3-5-371, lettre de Le Corbusier à Chinubhai Chimanbhai, 1954.9.22.

注83) 壁と一体化する新しい「壁」の追求の一方で、ヴィラ・サラバイ (1955) やヴィラ・ショーダン (1956) のアーメダバードの住宅作品の人工照明に ついては、一貫してル・コルビュジエ制作の工業製品を装備することを検 討している。cf., AFLC, P3-5-208, lettre de Jacques Michel à Manorama Sarabhai, 1953.9.8; AFLC, P3-7-109, lettre de Doshi à Jean-Louis Véret, 1953.9.8.

注84) “Qu'ai-je donné à Shodan? Un palais, = une maison fonctionnelle. Avec son argent et de du béton brut et de la couleur, je lui ai donné: l'ombre en été, le soleil en hiver, l'air circulant et frais, à toute saison. Des chambres normales chacun ayant sa chambre $=$ son abri $=\mathbf{s a}$ petite maison. Il sort de la petite maison sur la 1ère, deuxième terrasse, à l'ombre, à l'abri. Dans un air mouvant permanent. Il montre sur le toit, Il y dort. Partout lui ou ses hôtes, sont à l'abri, son captivés, enchantés. C'est un Château de la Loire? Oui pour un prince intelligent " (Le Corbusier, Le Corbusier Carnets 3 1954-1957, op.cit., p.451, 1955.11.13) 注85)「自然のコンディションの再確立」など時代錯誤、人工照明と空調があ るではないか、という批判をル・コルビュジェは未来主義として瓜けてい る。cf., Le Corbusier, op.cit., p.1078, 1957.11.1.

注86) 出典：筆者作成。

注87）したがってその寸法体系は、内法で決められているわけではなく、も のの実用性という側面は等閑視されている。

注88) cf., Le Corbusier, "Tapisseries Muralnomad », Zodiac, nº7, 1960, p.57.

注89) cf., Le Corbusier et son atelier rue de Sèvres 35, W. Boesiger éd., Euvre complète 1952-1957, Girsberger, Zürich, 1957, p.208.

注 90 ) cf., Le Corbusier, Précision, op.cit., p.116; Le Corbusier, L'Architecture d'Aujourd'hui, numéro hors série, "Le Corbusier ", 1946.4., p.3; Le Corbusier, Le Corbusier Carnets 4 1957-1964, op.cit., p.912, 1962.7. さらに遡れば、1919 年の東方への旅で体験したエマの僧院 の僧房における孤独と静寂の生活空間である。cf., AFLC, A3-1-324-333, “ Unité d'habitation de grandeur conforme », 1957.4.1.

本稿は科学研究費助成事業基盤研究（C）（一般）課題番号 $15 K 06399$ の研究 成果の一部である。 
REALIZATION OF THE STANDARD CABINET AS THE “EQUIPMENT” BY LE CORBUSIER:

Transformation of the "Wall"

Shoichiro SENDAI*1

${ }^{* 1}$ Assoc. Prof., Graduate school of Engineering, Hiroshima Univ., Dr.Eng.

This paper aims to clarify the spatial composition of the standard cabinets as the "equipment" by Le Corbusier (1887-1965), in order to discuss the revolution of the notion of interior "decor" in the 20th century.

At first, we pick up the discourse concerning the standard cabinets in the architectural projects for private houses, and classify them as the methodology of interior setting of a building (Chapter 2). Next, we extract the case examples of the studies of the cabinets from all Le Corbusier's private house projects, and clarify the secular change of the realization methods of the cabinets (Chapter 3). Finally, we discuss the reasons and the implications of such a transition about the spatial composition of houses (Chapter 4).

Le Corbusier has already proposed a prototype of interior life space in the occation of the construction of the pavilion L'Esprit Nouveau in 1925. At that time, he mentioned three methods of setting the standard cabinets: to incorporate ("incorporer") into the wall - cabinet (in) -, to put ("appuyer") on the wall - cabinet (app) -, and to separate ("disposer") from the wall - cabinet (dis) -. However, although he replaced the stylized furniture with a standardized mass production cabinets, he could not realize from the biginning all three types of the cabinets : cabinet (in), cabinet (app), and cabinet (dis) .

In the private house projects from the 1920 s to the 1930 s, cabinet (app) was often applied due to the restrictions on site conditions and the requests of daily life from the owners. This is methodologically the same as the setting of the conventional decorative arts. Houever, what Le Corbusier aimed was the cabinet (dis) as partition separaterd frome the wall to escape from the trational furniture as the decorative arts. It was greatly affected by the opportunities of the mass-produced housing researches after the First World War and of constructions at the remote locations. That is, it was necessary for the architect to detach the cabinets from the immovable wall surface in order to automatically set up them without controlling all construction processes on the spot far from the architect. It was also partly effective to answer the details of various requests of the owners. Such a cabinet (dis) has been continuously studied after the Second World War, and finally, it was not only independent from the wall, but also it was itself being studied as movable cabinets.

On the other hand, the cabinet integrated with the wall, which could not be realized in the 1920s, was examined by houses with vault roofs. Unlike houses with pillars and floors as structural framework, Le Corbusier examined the cabinet incorporated into the wall, due to the large number of walls supporting the vault roof. Such a cabinet (in) was pursued further in India under the tropical climatic conditions, for the necessity of ventilation not obstructed by furniture.

The realization of the standard cabinets by Le Corbusier does not develop linearly, but expands to the both poles while continuing to the methodology of the decorative arts. Although this result seemingly contradicts, whether movable cabinet or incorporated cabinet, it can be thought that Le Corbusier's studies of the standard cabinet was the research of a new "wall". 